\title{
USING AIRBORNE LASER SCANNING DATA FOR AUTOMATION LAND COVER MAPPING IN THE ASPECT OF MONITORING FOREST SUCCESSION AREAS
}

\author{
University of Agriculture in Krakow \\ Faculty of Forestry, Institute of Forest Resources Management \\ Department of Forest Management, Geomatics and Forest Economics
}

Keywords: airborne laser scanning, nDSM, zonal statistics, vectorization orthophotomap

\begin{abstract}
Paper concerning possibilities of using airborne laser scanning (ALS) data for monitoring land cover changes, mainly land abandonment, especially for the aspect of detection forest succession area. Automated method was developed based on the product of ALS data processing - normalized Digital Surface Model (nDSM). The results of ALS data processing were compared with the official cadastral data and the result of photointerpretation and manual vectorization orthophotomap.

As a test site was chosen area in Wieliczka district (Małopolska voivodship, south of Poland). The area of study consisted of several plots listed in the cadastral database mainly as agricultural areas, meadows or pastures but most of them not used for agriculture, but abandoned and covered by process of the secondary forest succession. Detailed information about actual land cover was determined for year 2012 based on ALS data from ISOK project (Head of Geodesy and Cartography).

Research showed discrepancy between the cadastral data and actual state for plots. Using ALS data, there was possibility in the semi-automatic way to confirm the process of forest succession in the analysed area, according to the results of vectorization orthophotomap.
\end{abstract}

\section{ZASTOSOWANIE DANYCH LOTNICZEGO SKANOWANIA LASEROWEGO DLA AUTOMATYZACJI OKREŚLANIA POKRYCIA TERENU W ASPEKCIE MONITOROWANIA OBSZARÓW SUKCESJI LEŚNEJ}

Słowa kluczowe: lotniczy skaning laserowy, zNMPT, analizy przestrzenne, wektoryzacja ortofotomapy

\begin{abstract}
Abstrakt
Artykuł dotyczy oceny możliwości zastosowania danych z lotniczego skanowania laserowego (ALS) do monitorowania pokrycia terenu, głównie w aspekcie detekcji zmiany użytkowania rolniczego gruntów i postępującego procesu sukcesji leśnej. Metoda zautomatyzowana została opracowana w oparciu o produkt przetwarzania danych ALS - znormalizowany Numeryczny Model Pokrycia (zNMPT). Wyniki porównano z danymi ewidencyjnymi oraz wynikiem fotointerpretacji i wektoryzacji ortofotomapy.

Jako obszar testowy wybrano teren w powiecie wielickim (woj. małopolskie). Obszar badań obejmował kilkadziesiąt działek wyszczególnionych w ewidencji gruntów jako tereny rolnicze, łąki lub pastwiska Większość analizowanych działek nie była użytkowana rolniczo, lecz objęta procesem wtórnej sukcesji leśnej. Szczegółowe informacje o aktualnym pokryciu terenu określono na rok 2012 w oparciu o dane ALS z projektu ISOK (Główny Urząd Geodezji i Kartografii).

W wyniku opracowania wskazano rozbieżności pomiędzy danymi katastralnymi a stanem rzeczywistym. Wykorzystując dane ALS, w zautomatyzowany sposób można było potwierdzić postępujący proces sukcesji leśnej na analizowanym obszarze w odniesieniu do wyników wektoryzacji ortofotomapy.
\end{abstract}




\section{INTRODUCTION}

Dynamically progressing land use changes (Bergen, Dronova 2007; Bowen et al. 2007; Lasanta et al. 2017; Lieskovský et al. 2015; Navarro, Pereira 2012) result in undertaking scientific works and implementations, among on the topics of forest succession (Kolecka et al. 2016; Śmigielski et al. 2017; Szostak et. al. 2018), $\mathrm{CO}_{2}$ sequestration and biomass (Susyan et al. 2011) in the ecosystem including in particular: analyses of their spatial distribution, seasonal variability, dynamics of changes in availability, as well as strategies for shaping renewable energy resources and their usage (e.g. calorific value).

Monitoring land use/ land cover (LULC) changes is also extremely important in relation to European Union agricultural programs and policy, including proper management of agricultural areas by maintaining them in good agricultural culture. European Union member countries are obliged to carry out a series of check-ups in farms and agricultural holdings in the framework of the Integrated System of Management and Control, which makes sure that all the payments for farmers from European Union budget are correctly administered. New regulations (European Commission, 2018) allow the willing states to replace or supplement the control system is the agricultural holdings with auto- mated and less stressful actions. Several member states have already expressed the will to start new technologies - the European Commission informs. Countries will be free to choose whether to apply a new monitoring approach. They will be able to decide if this should be applied in specific aid programmes and extend the area covered by monitoring within the first two years of the implementation of these techniques.

The general aim of this work was to define the possibilities of using airborne laser scanning (ALS) data and geoinformation technologies for automation in LULC classes monitoring, in the aspect of land abandonment and the exclusion of land from agricultural production to forest succession areas. Due to available for the whole Poland ALS data from ISOK project ( $p l$. ,,Informatyczny System Osłony Kraju przed nadzwyczajnymi zagrożeniami") and taking into account the possibility of using the remote sensing data (satellite laser scanning data - Global Ecosystem dynamics Incestigation GEDI and ICESat-2 have just started mission), it is reasonable to develop methods their automatic processing for the implementation of comprehensive study. Using laser scanning data will enable the development of automated methods for generating databases and maps e.g., forest areas / non-forest areas, forest biomass distribution maps, LULC changes and forest height (Ewijk et al. 2011, Falkowski et al. 2009, Kolecka et al. 2015).

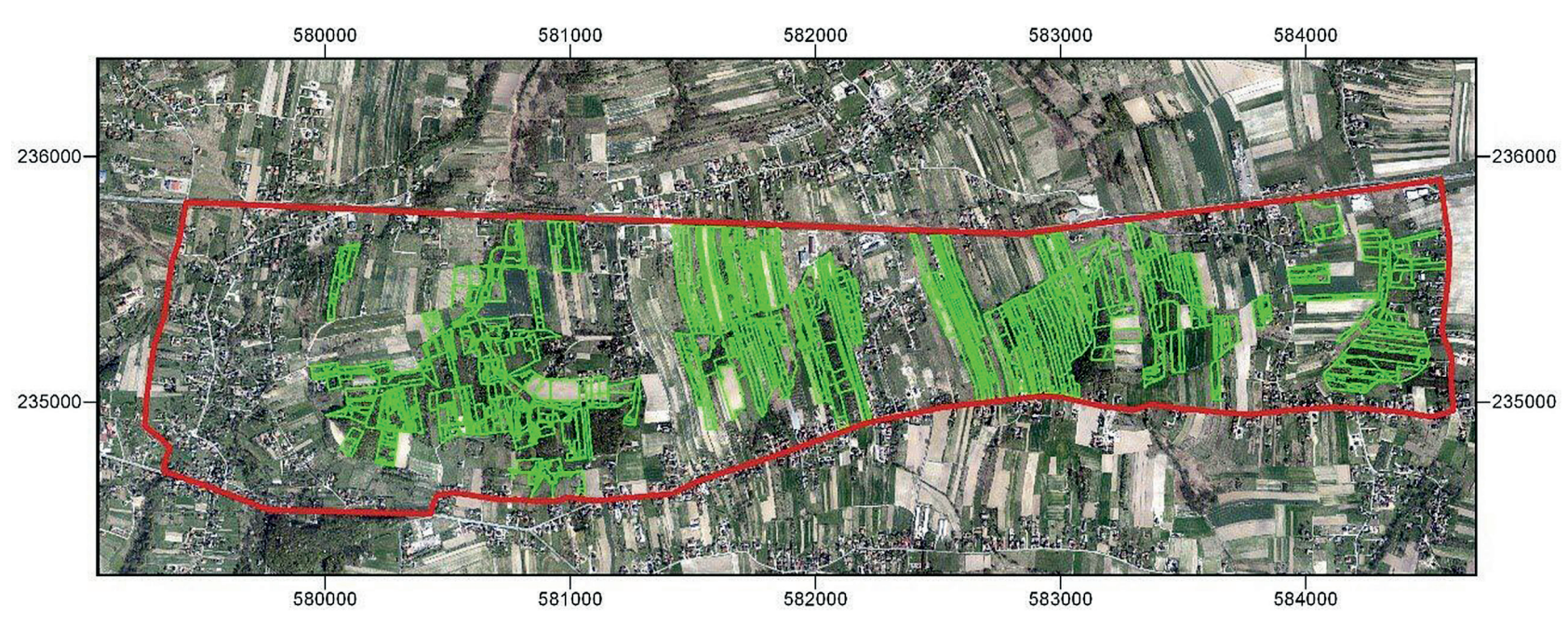

Fig. 1. The study area: general range - red colour; parcels analysed in details - green; background: orthophoto Rys. 1. Obszar badań: zakres opracowania - kolor czerwony, analizowane szczegółowo działki - zielony; tło: ortofotomapa 


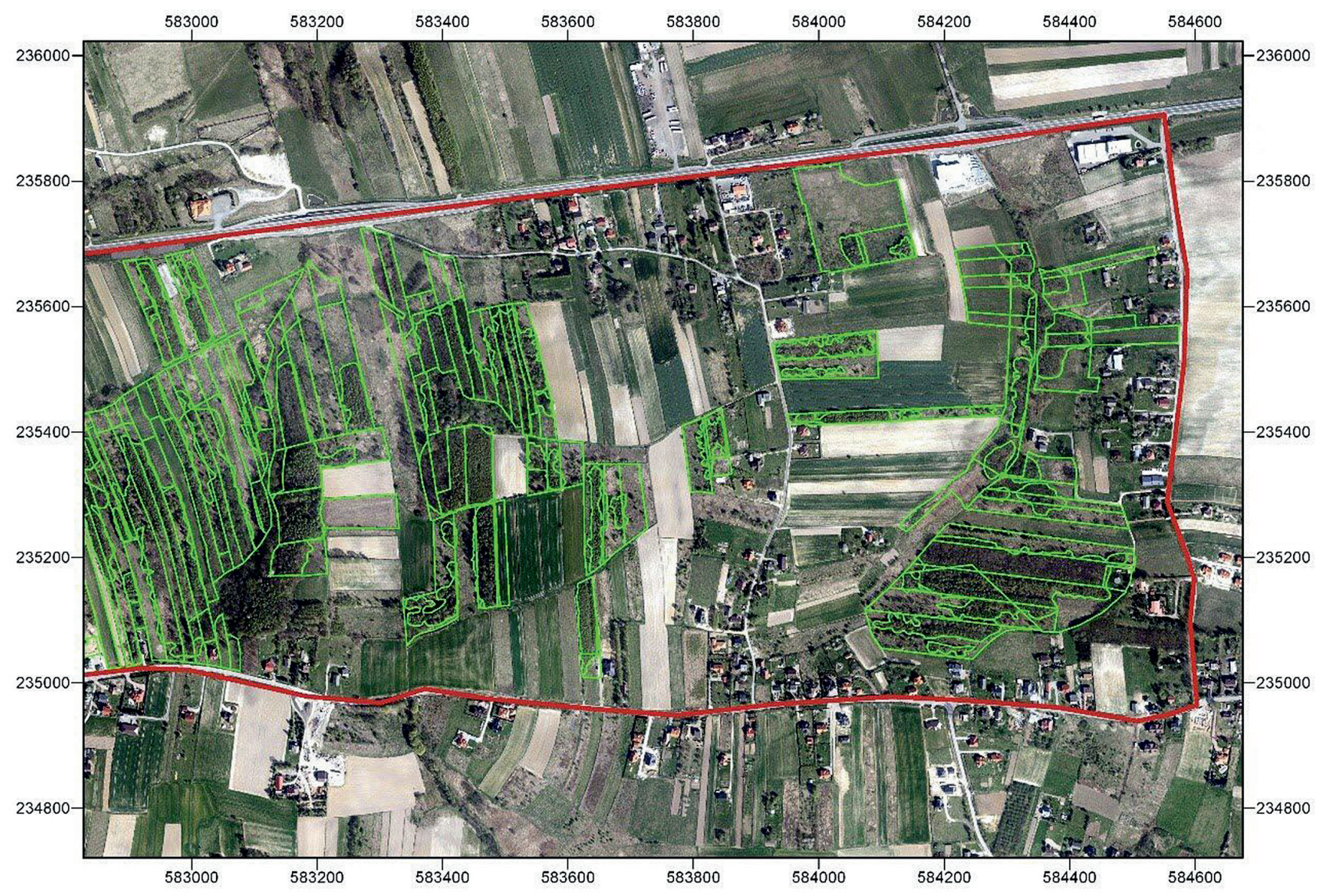

Fig. 2. Detailed view for the part of study area; background: orthophoto

Rys. 2. Szczegółowy widok fragmentu terenu badań; tło: ortofotomapa

\section{Study area, Materials and Methods}

The study area (Fig. 1) is a part of Biskupice community - Wieliczka district, Małopolska voivodeship (south of Poland). Analysed parcels were situated in the area where we can observe LULC changes dynamics land abandonment and increasing process of secondary forest succession. The total area of analysed parcels was 139.77 ha.

The study was carried out based on the orthophotomaps (coordinates system: PL-PUWG1992, GSD: $0.25 \mathrm{~m}$ ) and airborne laser scanning (ALS) point clouds $\left(6\right.$ points $\left./ \mathrm{m}^{2}\right)$ from ISOK project - pl. „Informatyczny System Ostony Kraju przed nadzwyczajnymi zagrożeniami", source: Main Office of Geodesy and Cartography (pl. Główny Urząd Geodezji i Kartografi; GUGiK).

For analyse were chosen parcels listed in the ground cadastre mainly as Arable land (A) - pl. Grunty orne
(R), Meadow (M) - pl. Eaki trwałe (Ł) or Pasture (P) pl. Pastwiska trwate $(\mathrm{P})$ but not used as agricultural land - areas of secondary forest succession. Detailed view for the part of study area is presented in Fig. 2.

Airborne laser scanning point clouds (2012) processing was carried out in FUSION Version 3.50 (R.J. McGaughey, Pacific Northwest Research Station; McGaughey, 2012) with LAStools (Rapidlasso GmbH). The first step was to generate a DTM (Digital Terrain Model) and a DSM (Digital Surface Model). This was done by using GridSurfaceCreate and the CanopyModel function. Normalized DSM (nDMS=DSM-DTM) was prepared using Raster Calculator (ArcGIS, Esri). Reclassification of the nDSM (Reclassify, ArcGIS) was carried out using $>1 \mathrm{~m},>2 \mathrm{~m}$ and $>3 \mathrm{~m}$ for the pixel value, representing the height of vegetation above the ground (Szostak et al., 2014; Szostak et al., 2018; Wężyk et al. 2009). To prepare the area $n D S M>1 \mathrm{~m}$ inventory in the whole study area, Zonal Statistics as 


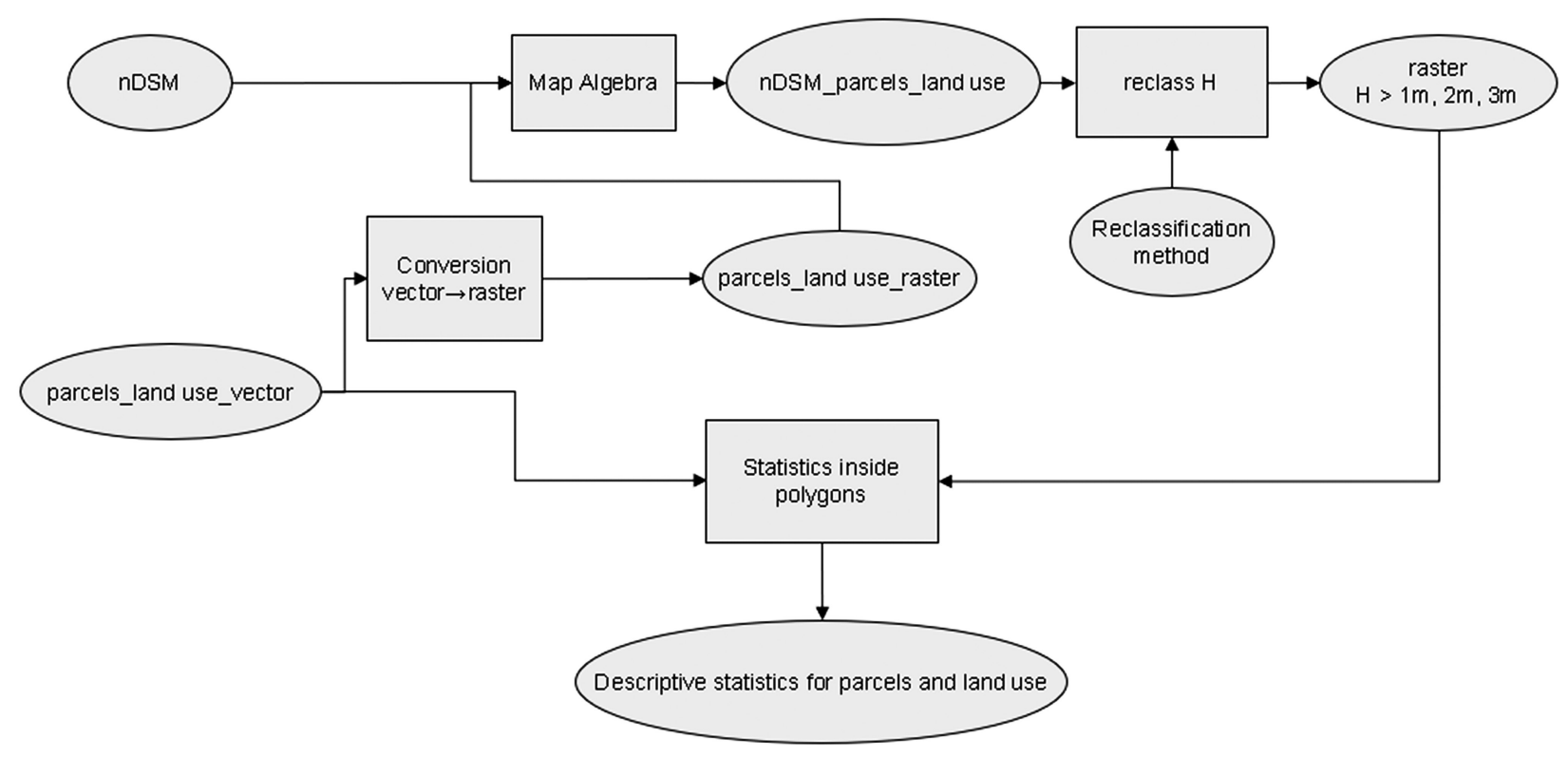

Fig. 3. The scheme of analysis

Rys. 3. Schemat analiz

Table function (ArcGIS) was applied. The scheme of analyses is presented in Fig. 3 .

The graphical results and the value of total area detected as forest succession based on reclassify $\mathrm{nDSM}$ were compared to the results of photointerpretation and manual vectorization orthophotomap. This allowed for analysis of the occurrence of succession processes in the studied area - in detail, the areas of progressive land abandonment.

Using airborne laser scanning data gives precise spatial characteristics of forested, wooded and bushy areas (Kolecka 2018, Naesset, Okland 2002, Tompalski 2012). This diversity is visible in the surface size (2D), the vertical vegetation structure (3D) and in the time dimension (4D).

\section{RESULTS}

The graphical result of the photointerpretation and vectorisation orthophotomap and on the other side reclassification of $\mathrm{nDSM}>1 \mathrm{~m}$ for some part of study area is presented in Fig. 4.

The results of processing ALS data - reclassification of $\mathrm{nDSM}>1 \mathrm{~m},>2 \mathrm{~m}$ and $>3 \mathrm{~m}$ for the whole analysed area, connected to the official cadastral data and the results of vectorization orthophotomap are collected in Table 1.
In the analysed area (Tab. 1; total area: $139.77 \mathrm{ha}$ ), official cadastral data showed the total of Forested area (F) - pl. Lasy (Ls) and Grunty zadrzewione i zakrzewione (Lz) as 6.37 ha $(4.56 \%$ of the analysed area). As a result of photointerpretation and manual vectorization of the orthophotomap there was 29.92 ha $-21.41 \%$ of the analysed area, so forest succession areas had value 23.55 ha $-16.85 \%$ of the analysed area. Based on the reclassified $\mathrm{nDSM}>1 \mathrm{~m}$ forest succession areas had a little bit smaller value 19.07 ha $-13.64 \%$. The real use of the areas of Arable land (A) and Meadow (M) based on orthophotomap was about $12.18 \%$ and $4.29 \%$ less of that figured in the cadastral data. Based on $\mathrm{nDSM}>1$ it was decreased value: $10.68 \%$ for Arable land (A) and $2.48 \%$ for Meadow (M).

Value of reclassified nDSM confirmed the results from previous papers (Szostak et. al, 2014, Szostak et. al., 2018) for another analysed area (Milicz district, central west part of Poland) - analyses based on reclassified $\mathrm{nDSM}>1 \mathrm{~m}$ give the closest results to the vectorization of orthophotomap. At the study area (Tab.1) it was difference for Forested area (F) in value 3.21\% of the analysed area, $1.50 \%$ for Arable land (A) and $1.82 \%$ for Meadow (M).

Differences between the result of total area for reclassification $\mathrm{nDSM}>1 \mathrm{~m},>2 \mathrm{~m}$ and $>3 \mathrm{~m}$ showed differences in height of forest succession vegetation. Dif- 
a)

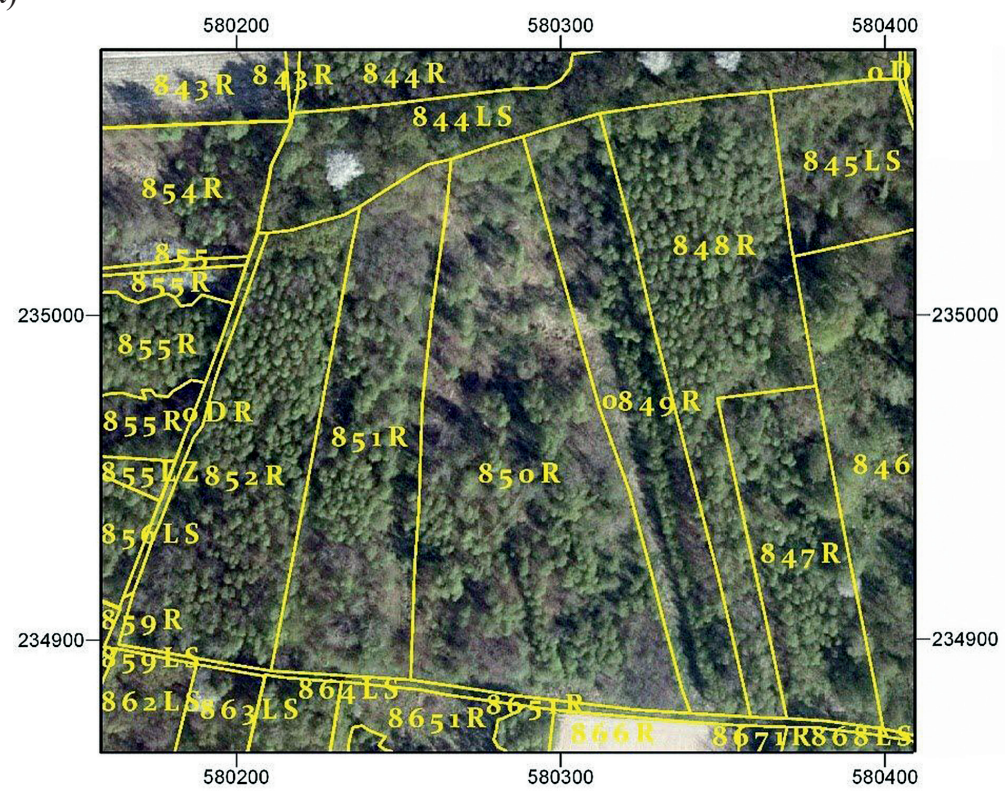

b)

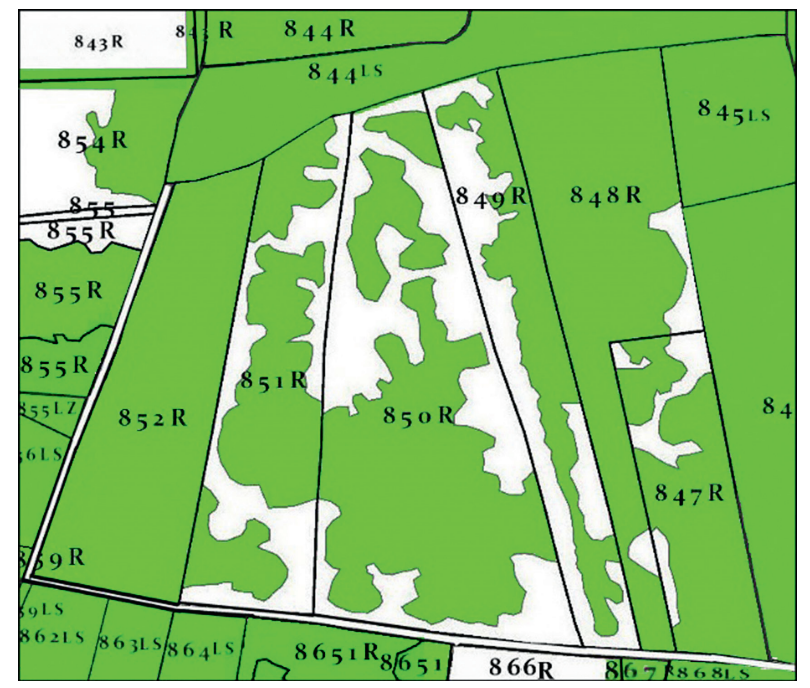

c)

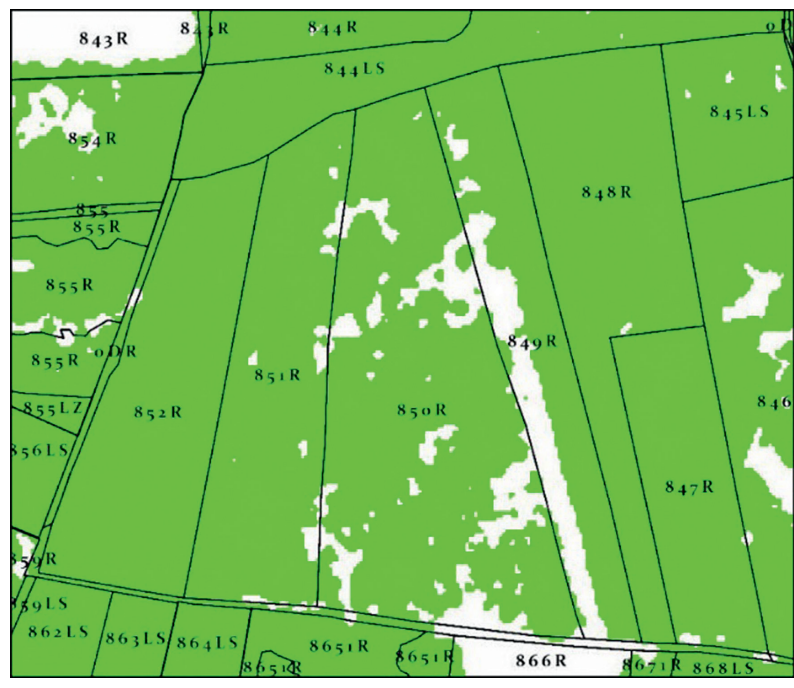

Fig. 4. Part of the study area: a) orthophotomap; b) result of manual vectorisation; green - forest succession; c) result of reclassification of $\mathrm{nDSM}$, green colour - vegetation height $>1 \mathrm{~m}$; background: cadastral data

Rys. 4. Fragment analizowanego obszaru: a) ortofotomapa; b) wynik wektoryzacji ortofotomapy; c) wynik reklasyfikacji zNMPT; kolor zielony - wysokość roślinności >1 m; tło: dane katastralne

ferences between $\mathrm{nDSM}>1 \mathrm{~m}$ and $\mathrm{nDSM}>2 \mathrm{~m}$ had total area (Tab.1) in value 3.58 ha $(2.56 \%$ of the analysed area). For $n D S M>1 m$ and $n D S M>3 m$ it was 4.49 ha $(3.21 \%)$. Therefore, it can be stated that forest succession being started some year ago but still increasing.

Part of the study area - profile from ALS data as an example of forest succession area is presented in Fig. 5.

\section{CONCLUSIONS}

The study presents assessment of using airborne laser scanning data for monitoring LULC changes mainly in the aspect of forest succession and afforestation of agricultural land. Public registers in the field of cadastral maps and land cover and use in Poland are of- 
Tab. 1. Land use in the study area - result of ALS data processing (reclassified nDSM). Classes: Forested area (F), Arable land (A), Meadow (M) Pasture (P) and Other (O).

Tab. 1. Klasy pokrycia terenu w obszarze badań - wynik przetwarzania danych ALS (reklasyfikowany zNMPT). Klasy: Lasy oraz Grunty zadrzewione i zakrzewione (F), Grunty orne (A), Eaki (M); Pastwiska (P) i Inne (O).

\begin{tabular}{|c|c|c|c|c|c|c|c|c|}
\hline \multirow{3}{*}{$\begin{array}{c}\text { Land } \\
\text { use }\end{array}$} & \multicolumn{5}{|c|}{ Area [ha] } & \multicolumn{3}{|c|}{ Difference [ha] } \\
\hline & \multicolumn{5}{|c|}{ Percentage [\%] } & \multicolumn{3}{|c|}{ Percentage $[\%]$} \\
\hline & $\begin{array}{c}\text { Cadastral } \\
\text { data }\end{array}$ & Ortho & $\begin{array}{c}\mathrm{nDSM} \\
>1 \mathrm{~m}\end{array}$ & $\begin{array}{c}\mathrm{nDSM} \\
>2 \mathrm{~m}\end{array}$ & $\begin{array}{c}\mathbf{n D S M} \\
>\mathbf{3 m}\end{array}$ & $\begin{array}{l}\text { Orthophoto - } \\
\text { Cad. data }\end{array}$ & $\begin{array}{c}\mathrm{nDSM}>1 \mathrm{~m}- \\
\text { Cad. data }\end{array}$ & $\begin{array}{c}\text { nDSM }>1 \mathrm{~m} \\
\text { - Orthophoto }\end{array}$ \\
\hline \multirow{2}{*}{$\mathrm{F}$} & 6.37 & 29.92 & 25.44 & 21.86 & 20.95 & 23.55 & 19.07 & -4.48 \\
\hline & 4.56 & 21.41 & 18.20 & 15.64 & 14.99 & 16.85 & 13.64 & -3.21 \\
\hline \multirow{2}{*}{ A } & 101.68 & 84.65 & 86.75 & 89.69 & 90.3 & -17.03 & -14.93 & 2.10 \\
\hline & 72.75 & 60.56 & 62.07 & 64.17 & 64.61 & -12.18 & -10.68 & 1.50 \\
\hline \multirow{2}{*}{$\mathrm{P}$} & 1.65 & 1.13 & 0.97 & 1.02 & 1.04 & -0.52 & -0.68 & -0.16 \\
\hline & 1.18 & 0.81 & 0.69 & 0.73 & 0.74 & -0.37 & -0.49 & -0.11 \\
\hline \multirow{2}{*}{ M } & 24.74 & 18.74 & 21.28 & 21.87 & 22.15 & -6.00 & -3.46 & 2.54 \\
\hline & 17.70 & 13.41 & 15.23 & 15.65 & 15.85 & -4.29 & -2.48 & 1.82 \\
\hline \multirow{2}{*}{$\mathrm{O}$} & \multicolumn{5}{|c|}{5.33} & & \multirow{4}{*}{\multicolumn{2}{|c|}{0.00}} \\
\hline & \multicolumn{5}{|c|}{3.81} & & & \\
\hline \multirow{2}{*}{ Total } & \multicolumn{5}{|c|}{139.77} & & & \\
\hline & \multicolumn{5}{|c|}{100.00} & & & \\
\hline
\end{tabular}

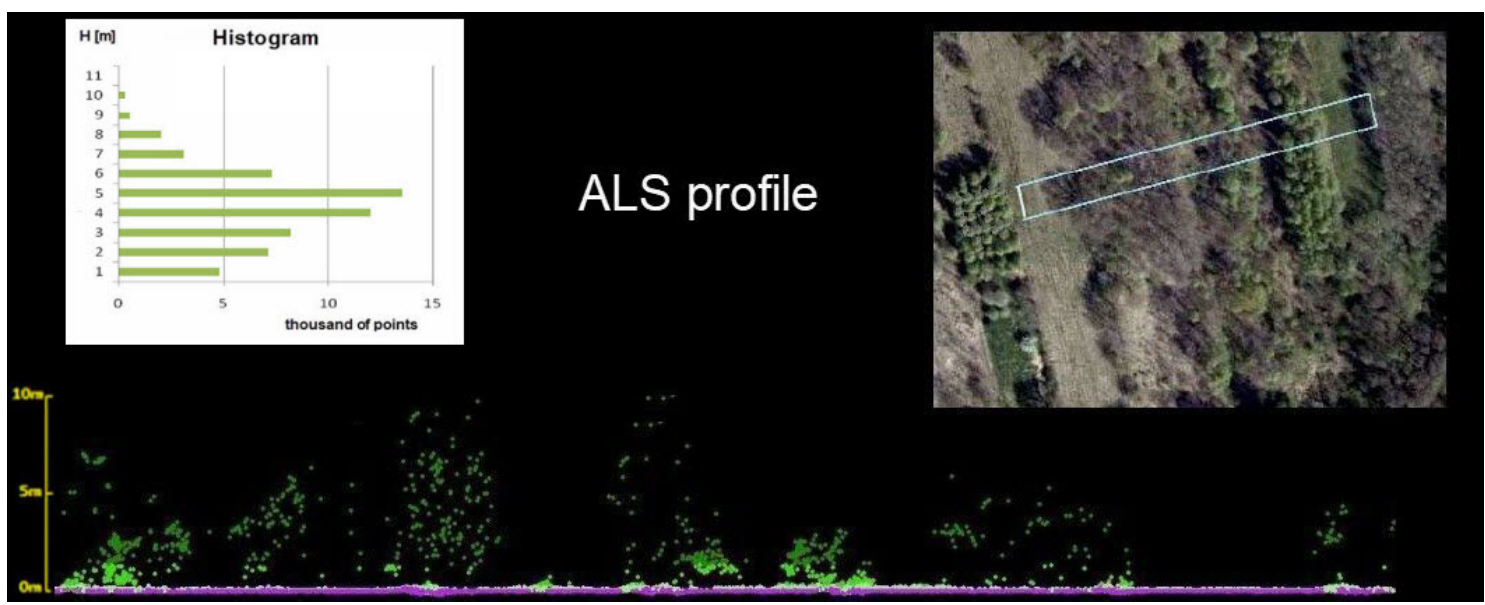

Fig. 5. ALS profile - example of forest succession area

Rys. 5. Profil z danych ALS - przykład obszaru sukcesji leśnej

ten outdated, which results from the high dynamics of changes taking place in agriculture as well as infrastructural and socio-economic changes taking place in rural areas. These are processes leading to an increase in the forest cover of the country, which is often not properly determined in the region, as it is based mainly on statistical and geodetic data - and not on currently acquired remote sensing data. 
Verification and updating data about dynamically increasing processes of secondary forest succession on post-agricultural land where agricultural use was stopped are very difficult and extremely costly in terms of using traditional methods. Therefore, it seems necessary to develop up-to-date biomass map of forested areas, bushes/shrubs for the entire country in order to verify available statistical data e.g. about forestation or about biomass. It is not without significance to develop a model based on current data on land cover and use. It is essential in terms of European Union programmes, including land management and the granting of direct subsidies to agriculture but also very important as a theme for the assessment of biomass.

\section{ACKNOWLEDGEMENTS}

This research was financed by the Ministry of Science and Higher Education, Poland.

\section{REFERENCES}

Bergen K.M., Dronova I. 2007. Observing succession on aspen-dominated landscapes using remote sensing-ecosystem approach. Landscape Ecology. 22, 1395-1410.

Błajda S. 2015. Monitoring of changes in EGiB database concerned forest succession based on orthophotomaps and airborne laser scanning data at the area of Milicz District. Dyploma thesis.

Bowen M.E., Mcalpine C.A., House A.P.N., Smith G.C. 2007. Regrowth forests on abandoned agricultural land: A review of their habitat values for recovering forest fauna. Biological Conservation. 140, 3-4, 273-296.

European Commission. 2018. Modernising the CAP: satellite data authorised to replace on-farm checks. NEWS, 25 May 2018, Brussels (https://ec.europa.eu/info/news)

Ewijk K.Y., Treitz P.M., Scott N.A. 2011. Characterizing forest succession in central Ontario using lidar-derived indices, Photogrammetric Engineering and Remote Sensing, 77 (3), 261-269

Falkowski M.J., Evans J.S., Martinuzzi S., Gessler P.E., Hudak A.T. 2009. Characterizing forest succession with lidar data: An evaluation for the Inland Northwest, USA, Remote Sensing of Environment, 113 (5), 946-956

Kolecka N. 2018. Height of Successional Vegetation Indicates Moment of Agricultural Land Abandonment. Remote Sensing 10 (10), 1568

Kolecka N., Kozak J., Kaim D., Dobosz M., Ginzler Ch., Psomas A. 2016. Mapping secondary forest succession on abandoned agricultural land in the Polish Carpathians. International Ar- chives of the Photogrammetry, Remote Sensing and Spatial Information Sciences - ISPRS Archives, 41, 931-935

Kolecka N., Kozak J., Kaim D., Dobosz M., Ginzler C., Psomas A. 2015. Mapping secondary forest succession on abandoned agricultural land with LiDAR point clouds and terrestrial photography, Remote Sensing, 7 (7), 8300-8322

Lasanta T., Arnáez J, Pascual N., Ruiz-Flaño P., Errea M.P., Lana-Renault N. 2017. Space-time process and drivers of land abandonment in Europe. Catena 149, 810-823

Lieskovský J. Bezák P., Špulerová J., Lieskovský T., Koleda P., Dobrovodská M., Bürgi M., Gimmi U. 2015. The abandonment of traditional agricultural landscape in Slovakia - Analysis of extent and driving forces, Journal of Rural Studies, vol. 37 , pp. $75-84$

McGaughey R.J. 2012. Fusion/ldv: Software for lidar data analysis and visualization. Software manual. USDA Forest Service. Pacific Northwest Research Station.

Naesset E., Okland T. 2002. Estimating tree height and tree crown properties using airborne scanning laser in a boreal nature reserve. Remote Sensing of Environment, vol. 79, s. $105-115$

Navarro L., Pereira H. 2012. Rewilding abandoned landscapes in Europe, Ecosystems, 15, 900-912

Susyan E.A., Wirth S., Ananyeva N.D, Stolnikova E.V. 2011. Forest succession on abandoned arable soils in European Russia - Impacts on microbial biomass, fungal-bacterial ratio, and basal CO2 respiration activity. European Journal of Soil Biology. 47, 3, 169-174.

Szostak M., Wężyk P., Tompalski P. 2014. Aerial Orthophoto and Airborne Laser Scanning as Monitoring Tools for Land Cover Dynamics: A Case Study from the Milicz Forest District (Poland). Pure and Applied Geophysics, vol. 171 (2014), No. 6, 857-866.

Szostak M., Hawryło P., Piela D. 2018. Using of Sentinel-2 images for automation of the forest succession detection. European Journal of Remote Sensing, 51, 1, 142-149

Szostak M., Wężyk P., Király G., Hawryło P., Bednarski A. 2018. Automation of forest succession dynamics using airborne laser scanning data. 18th International Multidisciplinary Scientific GeoConference SGEM 2018, www.sgem.org, SGEM2018 Conference Proceedings, 18, 2.3, 41-48

Śmigielski M., Pijanowski J., Gniadek J. 2017. Forest succession and afforestation of agricultural land as a current challenge agricultural works. Acta Sci. Pol. Formatio Circumiectus 16 (4) 2017, 51-63.

Tompalski P. 2012. The use of 3D spatial indices for urban vegetation analysis based on airborne laser scanning data. Archives of Photogrammetry, Cartography and Remote Sensing, vol. 23, s. 443-456.

Wężyk P., Szostak M., Tompalski P. 2009. Comparison of the accuracy of the "PHOTO" check method with automatic analysis based on ALS data for direct control of subsidy payments. Archives of Photogrammetry, Cartography and Remote Sensing 20, 445-456. 